\title{
Zygmunt Kaczkowski wobec tradycji sarmackiej w kontekście cyklu nieczujowskiego ${ }^{1}$
}

\author{
Agnieszka Szczechura (Humeniuk) \\ (Wojskowe Centrum Edukacji Obywatelskiej im. płk. dypl. Mariana Porwita, \\ Warszawa)
}

Zarówno we współczesnym świecie, jak i sięgając do wiedzy historycznej, można wskazać ciekawe przykłady niezwykłej popularności w danym czasie jakiejś idei, zjawiska, tendencji, mody czy osoby. W przypadku wielkich odkryć czy dokonań istotnych dla ludzkości pamięć o nich samych bądź o ich twórcach trwa niezmiennie, bardziej lub mniej dobitnie utrwalana w otaczającej rzeczywistości, choćby pod postacią nazw ulic i placów oraz pomników, instytucji, czy też uroczystych obchodów rocznicowych konkretnych wydarzeń lub faktów. Podobną tendencję można zaobserwować w przypadku wielkich literatów, a także wybitnie utalentowanych przedstawicieli innych dziedzin artystycznych - malarzy, rzeźbiarzy, muzyków.

1 Artykuł powstał na podstawie fragmentów rozprawy doktorskiej zatytułowanej Obraz czasów stanistawowskich w wybranych utworach Henryka Rzewuskiego i Zygmunta Kaczkowskiego, napisanej pod kierunkiem prof. dr hab. Marii Jolanty Olszewskiej, obronionej dnia 27 stycznia 2015 roku na Wydziale Polonistyki Uniwersytetu Warszawskiego. Pojęcie „cyklu nieczujowskiego” oznacza powieści i opowiadania, połączone postacią głównego bohatera, Marcina Nieczui. Część z nich pozostała jako pierwodruki wyłącznie na łamach czasopism lub w wydaniach dziewiętnastowiecznych. (Z. Kaczkowski, Bitwa pod Widawa. Rapsod wojenny, „Dziennik Literacki”1852, nr 20-22; Dziedzic Strwiążka. Powieśc z czasów rozbioru, „Pamiętnik Literacki. Pismo Tygodniowe” R. I, 1850, nr 28-29; Junakowie, w: idem, Dzieta, t. 1, Warszawa 1874; Pan Bal, „Gazeta Lwowska”1852, nr 18-19, 21-22, 24; Basia Karsznicka, w: idem, Dzieta, t. 3, Warszawa 1874; Edmund Chojnacki w: idem, Dzieta, t. 3, Warszawa 1874), nie weszła bowiem w skład edycji dzieł Zygmunta Kaczkowskiego, przygotowanej przez Antoniego Jopka (Z. Kaczkowski, Bitwa o chorążankę, w: idem, Opowiadania Nieczui, Kraków 1962; Gniazdo Nieczujów, w: idem, Opowiadania Nieczui, Kraków 1962; Idem, Kasztelanice lubaczerwscy, w: idem, Opowiadania Nieczui, Kraków 1962; Mą̇̇ szalony, Kraków 1963; Murdelio, Kraków 1959, t. 1-2; Pierwsza wyprawa pana Marcina, w: idem, Opowiadania Nieczui, Kraków 1962; Starosta hotobucki, Kraków 1961; Swaty na Rusi, w: idem, Opowiadania Nieczui, Kraków 1962; Grób Nieczui, Kraków 1964, t. 1-2). Ustalenie pełnego kanonu cyklu nieczujowskiego wymagałoby jednak dalszych badań. 
Niemniej jednak na przestrzeni wieków można wskazać wiele przykładów osób, które pomimo iż w swoim czasie lokalnie bądź w szerszym kręgu były bardzo popularne, to jednak - z bardzo różnych przyczyn - pamięć o nich nie przetrwała do naszych czasów, innymi słowy - została „utracona”.

Wielu przykładów takiej „utraconej sławy” dostarcza historia literatury. Można tutaj przywołać choćby postać Juliana Ursyna Niemcewicza, który w okresie porozbiorowym cieszył się dużą popularnością oraz społecznym szacunkiem i dla wielu ludzi tamtych czasów był uosobieniem polskości. Pomimo tego autor Śpierwów historycznych (I808-I8II) utracił popularność jako literat - współcześnie w świadomości młodzieży szkół średnich w zasadzie funkcjonuje jedynie jako autor pierwszej polskiej komedii politycznej Powrót posta (I79I).

Innym autorem, który utracił popularność, jest Zygmunt Kaczkowski. Pisarz ten to szczególny przypadek w dziejach polskiej literatury ze względu na pewien paradoks, jaki uderza w jego zachowaniu - rażący rozdźwięk między publicznymi deklaracjami ideowymi a tajną działalnością, sprzeczną z wartościami wyrażanymi w powieściach. Przeprowadzone do tej pory badania pozwalają domniemywać, że ów paradoks może wynikać z niewłaściwego odczytania wymowy cyklu nieczujowskiego, do czego mogła się przyczynić błędna edycja. By to zweryfikować, niezbędne będzie przeprowadzenie dalszych badań, w tym badań źródłowych, polegających na próbie dotarcia do rękopisów i porównania ich z opublikowanymi tekstami z uwzględnieniem niebeletrystycznych tekstów pisarza, w których zawarł swoje poglądy. Kolejną przyczyną wspomnianego paradoksu może być pomijanie lub niewystarczająco akcentowana $\mathrm{w}$ dotychczasowych badaniach świadomość historyczna pisarza, a co się z tym łączy, świadomość, w jaki sposób „uprawia się” historię i jak można nią manipulować - wpływać na to, by osadzała się ona w świadomości innych przez odpowiednie pisanie o niej. Kaczkowski obnaża te mechanizmy - w cyklu nieczujowskim bowiem pojawiają się pewne sygnały zarówno w warstwie fabularnej, jak i na poziomie struktury tekstu. Konfederacja barska okazała się nośnym tematem, ponieważ pisarz jako dziecko słuchał wielu opowieści dotyczących tego okresu i zainteresowany nimi postanowił, już jako dorosły człowiek, napisać na ten temat dzieło naukowe. W tym celu zebrał wiele różnego rodzaju materiałów źródłowych. Dzieło nie powstało, jednakże zgromadzony materiał posłużył jako fabuła tekstów beletrystycznych, a ponadto skłonił pisarza do refleksji nad metodologią historii jako nauki. Efektem tego są wspomniane już sygnały stosunku do tradycji sarmackiej innego niż powszechnie mu przypisywany. Występują one w warstwie strukturalnej (odautorskie wstawki metahistoryczne, akcentowanie różnych punktów widzenia, świadome odsłanianie mechanizmów powstawania mitów, plotki czy legendy, a także krytyczna postawa wobec źródeł wiedzy historycznej). Kaczkowski postrzegany był przez opinię publiczną jako piewca tradycji 
sarmackiej i utożsamiany ze środowiskami mającymi apologetyczny stosunek do przeszłości, a tymczasem okazał się szpiegiem na usługach rządu austriackiego. Gdy ten fakt wyszedł na jaw, autor bardzo poczytnych niegdyś powieści historycznych - konkurent samego Henryka Sienkiewicza - nie tylko stracił popularność wśród czytelników, ale także został wyparty ze świadomości społecznej. W tym kontekście motyw „utraty” w przypadku Kaczkowskiego znajduje zastosowanie na dwóch płaszczyznach: literackiej i ideowej. Jednak w swoich rozważaniach chciałabym przede wszystkim zwrócić uwagę na aspekt literacki „utraconego” mitu Kaczkowskiego. Interesujące jest bowiem, że owa „utrata” i brak pogłębionej - krytycznej - refleksji nad całością spuścizny tego pisarza doprowadziły do sytuacji, w której autora Murdelia (I852) w literaturze przedmiotu do tej pory postrzega się jako apologetę sarmatyzmu, co nie jest zgodne z prawdą. Uważna lektura cyklu nieczujowskiego oraz innych tekstów niebeletrystycznych tego twórcy prowadzi do wniosku, że „bard szlachty sanockiej” - posługując się określeniem Antoniego Jopka² - sam utracił mityczne wyobrażenia o sarmackiej przeszłości Rzeczypospolitej. Prezentowany tutaj tekst ma na celu opisanie - a przynajmniej zasygnalizowanie - jakie czynniki o tym zadecydowały. Tym samym widać, jak bardzo złożoną sprawą jest próba odniesienia motywu utraty do postawy Kaczkowskiego. Ponieważ rozważania poświęcone są różnym przejawom tracenia mitycznych wyobrażeń o tradycji sarmackiej przez popularnego niegdyś autora, główna uwaga w tych dociekaniach skupi się na literaturze oraz historii.

Zygmunt Kaczkowski to pisarz obecnie niemal całkowicie nieznany czytelnikom i prawie zupełnie zapomniany przez badaczy. Większość poświęconych mu prac powstała do lat 30. XX wieku³. Współcześnie pisano o nim w związku z rocznicami $^{4}$ i jego działalnością szpiegowską . Jedyną do tej pory powojenną publikacją

2 A. Jopek, Bard szlachty sanockiej. Opowiadania i powiesci historyczne Zygmunta Kaczkowskiego, Kraków 1974.

3 Jako przykłady można wskazać: Zygmunt Kaczkowski. Jego życie i dziatalność literacka. Zarys biograficzny Piotra Chmielowskiego (Petersburg 1898) oraz Zygmunt Kaczkorwski i jego czasy. Na podstawie źródet i materiatów rękopiśmiennych Adama Krechowieckiego (Lwów 1918). O twórczości Kaczkowskiego wspomina także Wincenty Pol (Pamiętnik Wincentego Pola do literatury polskiej XIX wieku, w dwudziestu prelekcjach mianych w radnej sali miasta Lwowa, stenografowanych pod dyrekcja L. Olewińskiego, profesora stenografi w Uniwersytecie Lwowskim, Lwów 1866, s. 302).

4 A. Bystrzyca, Życie jak powwieść. W stulecie śmierci Zygmunta Kaczkowskiego, „Forum Polonijne” 1996, nr 3(9).

5 E. Barwiński, Zygmunt Kaczkowski w świetle prawdy (1863-1871). Z tajnych aktów b. austriackiego ministerstwa policji, Lwów 1920; Z. Fras, W. Suleja, Poczet agentów polskich, Wrocław 1995, s. 62-71; S. Cenckiewicz, Agent Heubauer, „Wprost” 2008, nr 9; S. Duda, Wiedeñska wtyczka. Historia galicyjska, „Gazeta Wyborcza” 2014, nr 138, dodatek „Ale Historia” nr 24. Na temat działalności szpiegowskiej Kaczkowskiego pisze także Magdalena Micińska (eadem, Zdrada - córka nocy. Pojęcie zdrady narodowej w świadomości Polaków w latach 1861-1914, Warszawa 1998). Por. Z. Kaczkowski, Rerwolucyjne sądy i wyroki. Rzecz osobista, Paryż i Wiedeń 1866. 
w całości poświęconą twórczości tego autora pozostaje wnikliwe studium Antoniego Jopka ${ }^{6}$. Spuścizna Kaczkowskiego badana jest przede wszystkim w kontekście nurtu sarmackiego w polskiej literaturze 7 . Warto również wspomnieć, że teksty autora cyklu nieczujowskiego przywoływane są w wielu szczegółowych studiach o zróżnicowanej tematyce, na przykład poświęconych: metaforyce roślin $^{8}$, motywom węgierskim w literaturze polskiej ${ }^{9}$, kulturze regionalnej ${ }^{\mathrm{IO}}$. Ostatnio, w kontekście krytyki literackiej lat I851-1863, na temat Kaczkowskiego pisał Bartłomiej Szleszyński ${ }^{\text {II }}$. Powieściopisarstwu autorstwa Swatów na Rusi (1852) poświęcone zostały fragmenty wielu prac dotyczących dziejów powieści historycznej ${ }^{\mathrm{I} 2}$. Juliusz Kijas ${ }^{\mathrm{I} 3}$ i Tadeusz Bujnicki ${ }^{\mathrm{I}}{ }^{2}$ zwrócili uwagę na tę twórczość, porównując ją z dokonaniami literackimi Henryka Sienkiewicza. Warto zresztą zauważyć, że to właśnie on w Listach z podróży do Ameryki wspomina anegdotę dotyczącą jednej z powieści Kaczkowskiego - Murdeliona, historia ta następnie posłużyła za kanwę Latarnika. Jako oddzielną grupę tekstów historycznoliterackich poświęconych powieściom autora cyklu nieczujowskiego można traktować rozważania stanowiące odrębne artykuły lub rozdziały w obszerniejszych

6 A. Jopek, op. cit.

7 Zob. m.in. A. Waśko, Romantyczny sarmatyzm. Tradycja szlachecka w literaturze polskiej lat 18311863, Kraków 1995; B. Szleszyński, Zygmunt Kaczkorwski - między Pamiątkami Soplicy i Trylogia, w: idem, Przymierzanie kontusza. Henryk Rzewuski i Henryk Sienkiewicz - najwybitniejsi twórcy XIX-wiecznego nurtu sarmackiego, Warszawa 2007, s. 217-227; idem, Sarmacka codziennośc w powieściach Henryka Rzerwuskiego, Zygmunta Kaczkowskiego i Henryka Sienkiewicza, w: Codzienność w literaturze XIX (i XX) wieku. Od Adalberta Stiftera do wspótczesności, pod red. G. Borkowskiej i A. Mazur, Opole 2007, s. 385-396).

8 E. Słoka, Roślinność romantycznego cmentarza, w: Literacka symbolika roślin, pod red. A. Martuszewskiej, Gdańsk 1997, s. 112.

9 Zob.: A. Sieroszewski, Pierwsze powieści historyczne Mora Jokaiego i Zygmunta Kaczkowskiego, w: Z dziejów polsko-wegierskich stosunków historycznych i literackich, pod red. I. Csaplárosa i A. Sieroszewskiego, Warszawa 1979, s. 145-154; M. Koźmiński, A. Sieroszewski, O stereotypie Polaka i Wegra $w$ XIX i XX w., Warszawa 1980.

10 A. Jopek, Ziemia krośnieńska w twórczości Zygmunta Kaczkowskiego, Rzeszów 1966; A. Kowalik, Zygmunt Kaczkowski, człowiek i pisarz, czyli twórczość w smudze cienia, w: Ziemia krośnieńska w kulturze polskiej, pod red. H. Kurek, F. Tereszkiewicza, Kraków 1996, s. 57-64.

11 B. Szleszyński, Twoórczośc Zygmunta Kaczkowskiego w oczach krytyki (1851-1863), w: Dyskursy krytycznoliterackie 1764-1918. Wokót „Stownika polskiej krytyki literackiej”, t. 2, pod red. M. Strzyżewskiego, Toruń 2012, s. 139-155.

12 Jako przykłady można wskazać prace: T. Jeske-Choiński, Historyczna powieść polska. Studium krytyczno-literackie (od Niemcewicza do Kaczkowskiego), Warszawa 1899, s. 119-152; A. Sieroszewski, Wegierska i polska powieśs historyczna w dobie romantyzmu, Warszawa 1977, s. 83-85; K. Czachowski, Między romantyzmem a realizmem, oprac. A. Czachowski, wstępem poprzedził J. Maciejewski, Warszawa 1969, s. 219-230.

13 J. Kijas, Kaczkowski jako wspótzawodnik Sienkiewicza, Kraków 1926.

14 T. Bujnicki, „Trylogia” w kontekście dziewiętnastowiecznej powieści historycznej, „Przegląd Humanistyczny" 1992, nr 6, s. 29-45. 
pracach $^{\mathrm{I} 5}$. Wiele do wiedzy o twórczości autora Pierwszej wyprawy pana Marcina wnoszą przedmowy badaczy do poszczególnych wydań jego dzieł, na przykład tekst wstępny Zygmunta Szweykowskiego do Murdeliona ${ }^{\text {I6 }}$ czy Ignacego Chrzanowskiego do edycji zbiorowej z 1900 roku $^{17}$. Warto również wspomnieć, że fragmenty powieści historycznych Kaczkowskiego - Anuncjaty i Olbrachtowych rycerzy zostały zamieszczone $\mathrm{w}$ antologii poświęconej motywowi konia w literaturze polskiej ${ }^{\mathrm{i} 8}$. Tym samym twórczość Kaczkowskiego wpisywałaby się w pewnym stopniu w zakres modnych ostatnio animal studies. Fragmenty Murdelia i Braci ślubnych trafily ponadto do antologii tekstów literackich zawierających motywy modlitewne ${ }^{\mathrm{I}}$.

Postać Kaczkowskiego i jego pisarski dorobek z kilku względów zasługują na uwagę. Przede wszystkim należy zauważyć, że twórczość ta nie doczekała się jeszcze ujęcia monograficznego. Ważne i bardzo przydatne byłoby także opracowanie biografii pisarza, wzbogaconej o materiały pozyskane w trakcie kwerend w kraju i za granicą (Paryż, Wiedeń). Kilku istotnych tekstów niebeletrystycznych Kaczkowskiego nie uwzględniono dotychczas przy analizie jego twórczości, uzasadniona zatem wydaje się potrzeba rewizji skądinąd bardzo cennych rozpoznań poczynionych przez Antoniego Jopka. Należałoby również pomyśleć o przygotowaniu edycji krytycznej całej spuścizny tego pisarza. Warto nadmienić, że w ciągu ostatniego półwiecza z całego dorobku Kaczkowskiego wznowiono zaledwie dwie powieści: Murdelio $^{20}$ i Olbrachtowi rycerze $e^{2 \mathrm{I}}$, a niektóre dzieła w ogóle nie zostały wydane w tym stuleciu. Istnieją teksty prozatorskie jego autorstwa, które nie posiadają dwudziestowiecznych wydań lub które były drukowane jedynie na łamach dziewiętnastowiecznej prasy, jak na przykład: Bitwa pod Widawa. Rapsod wojenny („Dziennik Literacki” 1852, nr 20-22), Dziedzic Strwiązyka. Powieś́ z czasów rozbioru („Pamiętnik Literacki.

15 W. Bednarczyk-Sołtys, Zygmunt Kaczkowski-„Olbrachtowi rycerze”, w: Powieśc polska XIX wieku. Interpretacje i analizy, pod red. L. Ludorowskiego, Lublin 1992, s. 251-262; M.J. Olszewska, Opowieśc - Bogu karzacym (Zygmunt Kaczkowski, Olbrachtowi rycerze), w: eadem, Drogi nadziei. Polska proza historyczna z lat 1876-1939 wobec kryzysu kultury. Wybór, Warszawa 2009, s. 143-157; A. Jopek, Dwie powieści Zygmunta Kaczkowskiego o dwóch konfederacjach. („Sodalis Marianus” „,Anuncjata”), Rzeszów 1965; Z. Szweykowski, „Murdelio” Zygmunta Kaczkorwskiego, w: idem, Nie tylko o Prusie. Szkice, Poznań 1967, s. 125-138.

16 Z. Szweykowski, Wstęp do: Z. Kaczkowski, Murdelio. Powwieść, Kraków 1925, s. III-XXIV.

17 I. Chrzanowski, Zygmunt Kaczkowski. (Zarys życia i działalności), w: Z. Kaczkowski, Wybór pism, t. 1, Warszawa 1900, s. I-XXX.

18 „Koń ma duszę w sobie”, wybór Ł. Ginkowa, Kraków 1988.

19 Motywy modliterwne w prozie polskiej XIX i XX wieku, wybór i oprac. A. Bednarek, Niepokalanów 1988, s. 119-121. Zob. także Bibliografia literatury polskiej „Nowy Korbut”, oprac. zespół pod kier. I. Śliwińskiej i S. Stupkiewicza, t. 8. Romantyzm: hasta osobowe K-O, Warszawa 1969, s. 11-15 (hasło: Kaczkowski Zygmunt).

20 Z. Kaczkowski, Murdelio,Kraków 1974 (Wydawnictwo Literackie); Rzeszów 1989 (Krajowa Agencja Wydawnicza); Kraków 2003 (Towarzystwo Autorów i Wydawców Prac Naukowych „Universitas”).

21 Idem, Olbrachtowi rycerze, Warszawa 2012 (wydawnictwo Inicjał Andrzej Palacz). 
Pismo Tygodniowe” R. I, I850, nr 28-29), Pan Bal („Gazeta Lwowska” 1852, nr I8-19, 2I-22, 24). W zasobach bibliotecznych można również odnaleźć zupełnie nieznane badaczom niebeletrystyczne teksty Kaczkowskiego opublikowane w XIX wieku, takie jak: Mój pamiętnik z lat 1833-1843 (Lwów I899); Od autora. O wartości źródet rękopiśmiennych i ustnych tradycyj do historii drugiej potowy XVIII wieku ${ }^{22}$ (Warszawa 1874); Stowo o romantyzmie. Gawęda literacka (Lwów I89I); Kobieta w Polsce. Studium historyczno-obyczajowe (Petersburg 1895, t. I-2); Teka Nieczui. Postanie Jmé Pana Nieczui do Matych Polaków i Czerwonych Rusinórw, a które też i Wielcy Polacy na czas sobie czytać moga, dla zbudowania i dla krotochwili (Paryż 1883). Co ciekawe, mało znane - zapewne dlatego, Antoni Jopek pominą je w przygotowanej przez siebie edycji dzieł Kaczkowskiego - są również teksty beletrystyczne z dziewiętnastowiecznego wydania zbiorowego twórczości tego autora: Junakowie ${ }^{23}$, Tradycje sanockie. Basia Karsznicka ${ }^{24}$, Tradycje sanockie. Edmund Chojnacki ${ }^{25}$. Dopiero ich znajomość pozwala w pełni zrozumieć wymowę cyklu nieczujowskiego oraz poglądy jego autora na tradycję sarmacką ${ }^{26}$, co z kolei umożliwia weryfikację utrwalonych w literaturze przedmiotu, choć (jak się okazuje) niezgodnych z prawdą opinii ${ }^{27}$.

Należy mieć świadomość, że Kaczkowski jest niesłusznie utożsamiany z grupą pisarzy prezentujących apologetyczny stosunek do tradycji sarmackiej - jest to zbyt daleko idące uproszczenie. Autor Grobu Nieczui nawiązywał do tradycji sarmackiej i wykorzystywał jej elementy, kreując świat przedstawiony, fabułę oraz postaci bohaterów swoich dzieł. Jednakże uważny czytelnik utworów składających się na cykl nieczujowski, także tekstów opublikowanych jedynie na łamach dziewiętnastowiecznej prasy, zauważy w nich elementy polemiki z przeszłością sarmacką. Owa twórczość zdecydowanie różni się tym samym od wizji tradycji szlacheckiej, stworzonej przez pisarzy nurtu sarmackiego w literaturze polskiej XIX wieku, choćby Henryka Rzewuskiego ${ }^{28}$ czy innych autorów skupionych wokół „Tygo-

22 Idem, Od autora. O wartości źródet rękopiśmiennych i ustnych tradycyj do historii drugiej potowy XVIII wieku, w: idem, Dzieta, t. 1, Warszawa 1874.

23 Z. Kaczkowski, Junakowie, op. cit.

24 Idem, Tradycje sanockie. Basia Karsznicka, op. cit.

25 Idem, Tradycje sanockie. Edmund Chojnacki, op. cit.

26 Por. na przykład: U. Eco, Pomiędzy autorem i tekstem, w: idem, Interpretacja i nadinterpretacja, thum. T. Bieroń, Kraków 2008, s. 76-100.

27 Na przykład: „Dodatnie traktowanie przeszłości, a ściślej mówiąc - jej apologia - nabierało określonego sensu dopiero poprzez działania praktyczne: w utworach Grabowskiego, Rzewuskiego i Kaczkowskiego dokonywała się rehabilitacja tych sił, które w XVIII wieku zadecydowały o upadku Polski” (S. Burkot, Uwiktani w historię. Szkice o literaturze, autorach i utworach XIX i XX wieku, Kraków 2008, s. 79).

28 Zob. m.in.: Z. Szweykowski, Powieści historyczne Henryka Rzerwuskiego, Warszawa 1922; B. Szleszyński, Przymierzanie kontusza, op. cit:; I. Węgrzyn, $W$ świecie powieści Henryka Rzerwuskiego, Kraków 2012. 
dnika Petersburskiego", takich jak: Michał Grabowski, Józef Przecławski, Ignacy Hołowiński, Placyd Jankowski, Stanisław Chołoniewski, Karol Drzewiecki ${ }^{29}$. Do owego grona można również zaliczyć Józefa Ignacego Kraszewskiego, który miał przekonania zachowawczo-katolickie ${ }^{30}$ i początkowo identyfikował się z grupa pisarzy skupionych wokó „Tygodnika Petersburskiego”. Jednakże, jak zauważa Andrzej Ślisz, zakończył tę wspólpracę ze względu na odmienne poglądy dotyczące sposobu ukazywania przeszłości szlacheckiej ${ }^{3 \mathrm{I}}$.

Zygmunt Kaczkowski - mimo fascynacji historią, a zwłaszcza konfederacją barską i końcem XVIII wieku - wyraźnie odcina się od wyidealizowanych wyobrażeń na temat ostatnich lat niepodległego państwa polskiego. Wyjątkowy charakter jego postawy ujawnia się przede wszystkim w sferze idei oraz na obszarze stylistyki. W pierwszym przypadku jako przykład można przywołać negatywne wypowiedzi narratora cyklu nieczujowskiego i jego ojca na temat konfederacji barskiej, choćby w powieści Mqq̇ szalony czy w krótszych formach prozatorskich, takich jak Bitwa pod Widawa, Pan Bal. Ich wymowa jednoznacznie wskazuje na negatywną ocenę ruchu barskiego. Podobnie w zakresie stylistyki - pisarz w niezwykle interesujący sposób odsłania mechanizm manipulacji, gdy do utworu Kasztelanice lubaczewssy wplata mowę, którą konfederat Krzysztof Brześciański stara się zwerbować szlachtę do oddziałów barskich ${ }^{32}$. Bohater świadomie podejmuje odpowiednie działania i dobiera stosowne słowa. Chcąc zwerbować w szeregi konfederackie jak największe rzesze szlachty, nie pyta wprost, kto by tego chciał, lecz aranżuje spotkanie w winiarni - przygotowując $\mathrm{w}$ ten sposób właściwy grunt pod swoje wystąpienie:

\ Jeszcze słońce nie zaszło, kiedy u Łatesa w winiarni już jakie czterdzieści szlachty, poobsiadawszy stoły, wino piło i po trochę krzykało. Pan Krzysztof, pan Błoński i pan Cieszanowski, upatrzywszy już swoich, dobrze im dolewali, a opowiadając eventus i jednej, i drugiej co zwycięskiej batalii, serca im rozgrzewali, a jeszcze nikomu i głowa się nie rozgrzała, kiedy pan cześnikowicz Osuchowski, Jacek Koniecki i ze

29 Zob. m.in.: M. Inglot, Poglady literackie koterii petersburskiej w latach 1841-1843, Wrocław 1961; A. Nawarecki, hasło: Sarmatyzm, w: Stownik sarmatyzmu, Kraków 2002.

30 Zob. na przykład: J.I. Kraszerwski, oprac. W. Danek, Warszawa 1965.

31 Zob. m.in. A. Ślisz, Henryk Rzewuski. Życie i poglady, Warszawa 1986, s. 189 i in. Kraszewski swoje stanowisko w kwestii sposobu przedstawiania sarmackiej przeszłości zaprezentował w tekście Obrazy przesztości (J.I. Kraszewski, Obrazy przesztości, w: Kraszewski o porwieściopisarzach i powieści. Zbiór wypowiedzi teoretycznych i krytycznych, oprac. S. Burkot, Warszawa 1962). Na ten temat zob. także: A. Humeniuk, Portret Karola Radziwitta „Panie Kochanku” w cyklu radziwittowskim J.I. Kraszewskiego, w: Kraszewski i nowożytność. Studia, idea i układ tomu J. Ławski; red. nauk. A. Janicka, K. Czajkowski, Ł. Zabielski, Białystok 2015, s. 541-552.

Z. Kaczkowski, Kasztelanice lubaczerwscy, w: idem, Opowiadania Nieczui, Kraków 1962, s. 81 i nast. 
trzech Strzeleckich tak dobrze, jakby już byli zwerbowani, a wszyscy prawie bardzo dla sprawy pokaptowani ${ }^{33}$.

Swą przemowę Brześciański rozpoczyna od przedstawienia dotychczasowych losów konfederacji. Znamienny jest emocjonalny ton jego wypowiedzi. Określenia, jakimi się posługuje, stanowią doskonały przykład perswazyjnej funkcji języka ${ }^{34}$ :

》Jaśnie wielmożni, wielmożni a mnie wielce szanowni i mili mości panowie i bracia! Wiadomo jest wam, że przed dwoma laty jeszcze zawiązała się konfederacja w Barze w celu obronienia Rzeczypospolitej od cudzych zagonów, a wiary naszej świętej rzymskokatolickiej od napaści heteryków, kacerzy i wszystkich innych diabłów, nazwanych dysydentami... ${ }^{35}$

Duże znaczenie ma tutaj użyte przez bohatera słowo „diabły” - jednoznacznie kojarzące się ze złem i siłami nieczystymi. Mówca odwołuje się w ten sposób do emocji słuchaczy, którzy jawią się jako potencjalni obrońcy Rzeczypospolitej i wiary, co tym samym podkreśla ich pozycję w społeczeństwie. Przemawiający po nakreśleniu ogólnego tła wydarzeń odnosi się do perspektywy lokalnej - przywołuje informacje dotyczące udziału szlachty sanockiej w konfederacji barskiej. Jego wypowiedź krzepi serca sanoczan, wskazując na ich osobisty udział w ważnych wydarzeniach historycznych. Uwagę o niepowodzeniach mówca czyni pretekstem do wskazania na Bożą pieczę nad konfederatami, a tym samym również na wyjątkowe cechy szlachty sanockiej. Bohater Kasztelaniców lubaczerwskich bardzo umiejętnie buduje napięcie oraz świadomie nawiązuje do preferowanego przez ową zbiorowość systemu wartości, dzięki czemu skutecznie wpływa na świadomość słuchaczy. Przypominając zgromadzonej szlachcie o złożonej przysiędze, odwołuje się do jej honoru oraz do spraw ostatecznych. Co ważne, nie poprzestaje na ogólnym wspomnieniu przysięgi - akcesu do konfederacji. Przypomina i wylicza konkretne czynności, dzięki którym odbiorcy mają szansę wywiązać się ze złożonej przysięgi:

\S Sukursu w koniach i ludziach dostarczać, pieniędzmi, przyrządami, leguminami zasilać, własnymi rękami na każdym miejscu z nieprzyjacielem bić się, krew swoją do ostatniej kropli za dawne prawa i wiarę

33 Ibidem, s. 82.

34 Zob. m.in.: Akty i gatunki mowy, red. J. Bartmiński, S. Niebrzegowska-Bartmińska, J. Szadura, Lublin, 2004; Akty i gatunki mowy w perspektywie kulturowej, pod red. A. Burzyńskiej-Kamienieckiej, Wrocław 2012.

35 Z. Kaczkowski, Kasztelanice lubaczerwscy, op. cit., s. 83. 
świętą wysączyć, sztandaru konfederacji nigdy nie opuścić, z Rzeczypospolitej, a nawet każdy z swojej własnej zagrody, raczej kamień i wodę uczynić... ${ }^{36}$

Bohater bardzo zręcznie stopniuje napięcie. Aby osiągnąć zamierzony cel, w końcu bezpośrednio zwraca się do słuchaczy. Świadomie wskazuje na dotychczasowe niepowodzenia konfederacji, by zaznaczyć, że mimo to walka trwa, a w ten sposób chce udowodnić słuszność kontynuowania działań konfederatów. W wypowiedzi Krzysztofa Brześciańskiego znamienne są odwołania do wiary w niezawodność Bożej opieki ${ }^{37}$. Scena zarysowana w przytoczonym fragmencie powieści stanowi doskonały przykład, w jaki sposób można manipulować obrazem historycznym. Należy zauważyć, że narrator ma świadomość tych zabiegów bohatera: „Otóż na tym większą pokusę pan Krzysztof pieśń konfederacką zaintonował, pospolicie naówczas znaną i po obozach śpiewaną [...]" ${ }^{38}$. Znamienne jest również to, że w śpiewanej pieśni zawarto odniesienie do postaci wroga, który dręczy nieszczęśliwą, a zarazem wspaniałą ojczyznę. Całe przedsięwzięcie kończy się fiaskiem, o czym zadecydowało przedkładanie przez przemawiającego osobistych interesów nad dobro sprawy. Co ciekawe, pisarz w wyważony sposób wskazuje zarówno na negatywne, jak i na pozytywne cechy obu obozów ideowo-politycznych, które ścierały się w czasach stanisławowskich. Być może przyczyną takiego stanowiska jest fakt, że Kaczkowski zamierzał napisać naukowy tekst o konfederacji barskiej, uznał jednak, że zgromadzony materiał będzie niewystarczający ${ }^{39}$. Miał zatem w odróżnieniu od innych twórców nurtu sarmackiego - rozległą i gruntowną wiedzę oraz świadomość historyczną, co pozwoliło mu nawet w utworze beletrystycznym zachować dystans wobec opisywanych zjawisk i przedstawić swoje stanowisko w tych kwestiach. Dzięki temu jego powieści historyczne poświęcone okresowi barskiemu wyraźnie różnią się od innych dzieł dotyczących konfederacji. Jako

36 Ibidem.

37 Warto dodać, że Krzysztof Brześciański osiąnnął swój cel, przekonał szlachtę do wzięcia czynnego udziału w konfederacji, ale jednocześnie wdał się w spór o kawałek gruntu z panem Załęskim i tak się w nim zatracił, że sprawy konfederacji zeszły na boczny tor.

38 Z. Kaczkowski, Kasztelanice lubaczewscy, op. cit., s. 90.

39 Pisarz tak oto uzasadnia swoją decyzję: „do wyświecenia tej sprawy w sposób odpowiedni historycznej nauce obadwa te źródła, tak ustne tradycje, jak wyż wspomniane książki [m.in. Rulhière'a, Ferranda ,Kitowicza, Wybickiego - A. H.], okazały mi się wcale niedostateczne: albowiem pierwsze wnikały w rzecz tylko epizodycznie i nie stanowiły jeszcze wiarygodnego świadectwa, - a drugie, jeżeli były pisane przez obcych, to traktowały tę sprawę prawie tylko zewnętrznie, zaś pisane przez swoich dawały także tylko fragmenta bez ogólnego poglądu i związku z całością. Stąd cała ta sprawa wydawała mi się naówczas zanurzoną w takim chaosie, iż przy braku materiałów źródłowych, aktów i dokumentów współczesnych, o których wtedy prawie nic nie wiedziałem, uważałem za niepodobieństwo napisać o niej więcej, niżeli już napisano”. (Z. Kaczkowski, Od autora, ibidem, s. 3-4). 
przykład można wskazać choćby Pobitna pod Rzeszowem Szczęsnego Morawskiego, który pracował w Zakładzie Narodowym imienia Ossolińskich i podobnie jak Kaczkowski interesował się historią, a zwłaszcza konfederacją barską. Napisał nawet naukowy tekst na jej temat ${ }^{40}$, ale mimo to jego wizja sarmackiej przeszłości w przywołanej powieści jest wyidealizowana - całą konfederacje ukazał wyłącznie przez pryzmat charakteru i działań jednej postaci, Kazimierza Pułaskiego, odmalowanego jako bohater bez skazy.

W dużym uproszczeniu można stwierdzić, że „bard szlachty sanockiej” prezentuje postawę pośrednią pomiędzy krakowską i warszawską szkołą historyczną ${ }^{4 \mathrm{I}}$. Odpowiedzi na pytanie o przyczyny takiego stanowiska należy szukać w wymienianych już wyżej tekstach niebeletrystycznych jego autorstwa. Jawi się w nich bowiem jako człowiek o umiarkowanych poglądach ${ }^{42}$ i szerokich horyzontach myślowych, bardzo dobrze orientujący się we współczesnym mu świecie. Zgodnie z jego przekonaniami, historykowi - by mógł zarysować naukowy obraz przeszłości - niezbędne są: ,dostateczne materiały” (pisze o tym w Moim pamiętniku, nie wyjaśnia jednak, co dokładnie rozumie pod owym pojęciem), dystans czasowy do opisywanych wydarzeń oraz odpowiednia perspektywa. Warunki te postrzega jako niezbędne do stworzenia obiektywnego opisu przeszłości („bezstronnej historii”). Przy czym zdaje sobie sprawę z wybiórczego charakteru postrzegania i różnych punktów widzenia ${ }^{43}$. Wstępna wypowiedź Od autora, którą Kaczkowski poprzedził zbiorowe wydanie swoich dzieł, skłania do wniosku, że z dużym dystansem odnosił się on do wiedzy historycznej, którą zdoby1, studiując osiemnastowieczne rękopisy (między innymi w Zakładzie Narodowym im. Ossolińskich we Lwowie ${ }^{44}$ ), uświadamiał sobie bowiem różnicę między naukowym tekstem historycznym a beletrystycznym ${ }^{45}$. Co ciekawe, ślady wiedzy pisarza z zakresu metodologii historii można wskazać na konkretnych przykładach z cyklu nieczujowskiego, które dotyczą następujących zagadnień: źródła wiedzy, prawda, manipulowanie faktami, różne punkty widzenia,

40 Zob. H. Barycz, Rzeszowianin Szczęsny Morawski 15 V 1818-10 IV 1898, w: Sz. Morawski, Pobitna pod Rzeszowem. Powieść prawdziwa z czasów konfederacji barskiej z roku 1769, wyd. 3, Rzeszów 2004, s. 363 .

41 Najlepszym tego dowodem jest Teka Nieczui, w której pisarz polemizuje z poglądami szkoły krakowskiej. Tekst ten zasługuje na odrębne studium.

42 Widać je również choćby na przykładzie stosunku pisarza do tradycji ustnej. W jego przekonaniu, pomimo iż nie ma ona rangi wiedzy źródłowej, to jednak tworząc obraz przeszłości, nie należy jej bagatelizować. $Z$ tego powodu negatywnie wypowiadał się na temat Waleriana Kalinki, który w swoim opisie czasów stanisławowskich nie uwzględnił żywych tradycji. Zob. Z. Kaczkowski, Romantyzm, op. cit., s. 9, a także: Od autora, op. cit., s. 21 i in.

43 Idem, Mójpamiętnik z lat 1833-1843, Lwów 1899, s. 5.

44 Idem, Od autora, op. cit., s. 5 i in.

45 Zdaniem pisarza: „świat sztuki nie tymi się rządzi prawami co świat nauki, w którym zawsze się godzi na tym samym tle nowy malować obraz, jak tylko kilka nowych odkryje się rysów”. Ibidem, s. 44. 
legenda, pamięć, ślad, pamiątka. Stanowią one niezbity dowód, że autor „utracił” mityczne wyobrażenia na temat tradycji sarmackiej. W zamian poddał refleksji zagadnienie obiektywnego ujęcia przeszłości ${ }^{46}$, jej poznania i zrozumienia. Na taką postawę pisarza niewątpliwie bardzo silnie oddziałały jego osobiste doświadczenia. Wychowanie w patriotycznej atmosferze, fascynacja Wincentym Polem i jego twórczością oraz romantyczną literaturą i jej ideałami, spiskowa atmosfera Lwowa lat 30. XIX wieku - wszystkie te czynniki wywarły ogromny wpływ na światopogląd pisarza. Jednakże pod wpływem wydarzeń I846 roku w Galicji Kaczkowski jako ich świadek i uczestnik miał możliwość skonfrontowania wpojonych wartości z rzeczywistością. Spowodowało to u niego utratę młodzieńczych ideałów i doprowadziło do weryfikacji poglądów, o czym pisze wprost $\mathrm{w}$ swoim pamiętniku ${ }^{47}$. Jako człowiek oczytany, można nawet powiedzieć - światowy (bywalec Lwowa, Wiednia, Paryża), zaznajomiony $\mathrm{z}$ najnowszymi nowinkami naukowymi ${ }^{48}$ wypracował własny pogląd na historię, w tym również na tradycję sarmacką i powieść historyczną. Największą popularność przyniosły mu właśnie powieści historyczne dotyczące konfederacji barskiej. Jak wiadomo, konkurował z samym Sienkiewiczem, a nawet otwarcie z nim polemizował ${ }^{49}$.

Interesującym kontekstem dla rozważań nad wyjątkowością postawy Kaczkowskiego wobec sygnalizowanej kwestii w porównaniu ze stanowiskiem innych twórców zaliczanych do nurtu sarmackiego w literaturze polskiej XIX wieku jest zagadnienie zmiany sposobu postrzegania historii w tym stuleciu. Punkt odniesienia stanowi tutaj kwestia obiektywizmu w historiografii oraz jej wpływ na świadomość historyczną pisarza. W przypadku twórczości Kaczkowskiego zagadnienia te przekładają się na jego postawę wobec mitu sarmackiego - zdobyta wiedza zaowocowała zmianą sposobu postrzegania przeszłości i utratą apologetycznego wobec niej stosunku. Andrzej Feliks Grabski zauważa, że zmiana podejścia do historii w XVIII wieku na ziemiach polskich była ściśle związana z polityką, a nie $\mathrm{z}$ dążeniem do obiektywizacji przeszłości ${ }^{\circ}$, z czego Kaczkowski doskonale zdawał sobie sprawę, zarzucając polskiej historiografii brak metody $i$ „propagandę patriotyczną"5x. Pisarz stwierdził również, że na gruncie polskiej nauki historycznej małą popularnością cieszą się wydawnictwa źródłowe ${ }^{52}$. Być może pewien wpływ

\footnotetext{
46 Por. na przykład G.W.F. Hegel, Fenomenologia ducha, tłum. Ś.F. Nowicki, Warszawa 2010.

47 Z. Kaczkowski, Mój pamiętnik z lat 1833-1843, op. cit., s. 69.

48 Zob. na przykład: Z. Kaczkowski, Romantyzm, op. cit.

49 Zob. J. Kijas, op. cit.

50 A. F. Grabski, Dzieje historiografi, wprowadzenie R. Stobiecki, Poznań 2003, s. 388-389.

51 Z. Kaczkowski, Romantyzm, op. cit., s. 57.

52 Idem, Od autora, op. cit., s. 43.
} 
na jego świadomość wywarły poglądy Naruszewicza, którego „weryfikujące podejście" do sarmackiej przeszłości stało się popularne od lat 8o. XVIII wieku, na który to okres Grabski datuje początek profesjonalnego podejścia do historii. Co ciekawe, echa owych tendencji odnajdziemy w powieściach historycznych zarówno Kaczkowskiego (Starosta hotobucki, 1856), jak i Kraszewskiego (Boża opieka, 1873). Czas formowania się światopoglądu pisarza i jego świadomości historycznej zbiega się z nową fazą polskiego dziejopisarstwa, która przypada na trzy początkowe dekady XIX wieku ${ }^{53}$. Popularyzowany wówczas model badań w owej dziedzinie, opierający się na metodach nauk przyrodniczych, odcisnął piętno na przekonaniach Kaczkowskiego:

\Bogatych kruszców leżących we wnętrznościach ziemi, miast zasypanych wybuchami wulkanów, przedpotopowych światów, nakrytych namuliskami wieków, każdy się dokopie, kto zechce, ale Cuvier ${ }^{54}$ dopiero składa z kilku kosteczek postać całego zwierza. I na wykopaliskach takich poznać się także nie łatwo, bo jak już wyżej wspomniałem, najtrudniejszą do dojrzenia jest właściwie ta prawda, która tu leży przed nami; jeszcze daleko trudniejszą do dojrzenia jej żywotność, jej wzniosłość, jej pięknośćc5.

Najlepszym dowodem wspomnianego wpływu jest przywołanie przez pisarza nazwiska francuskiego biologa. Jak bowiem zauważa Bartłomiej Szleszyński, „już w latach 40. przy okazji pisania o powieściach historycznych przywołuje się nazwisko Cuviera, które zwykliśmy kojarzyć dopiero z pozytywistyczną dyskusją o powieści historycznej” ${ }^{56}$.

Model badań historiograficznych oparty na wzorach właściwych naukom przyrodniczym cechuje bezstronność i obiektywizm, które to elementy uważny czytelnik dostrzeże w postawie Kaczkowskiego jako autora cyklu nieczujowskiego. Jego troska o pozbawione tendencyjności i subiektywizmu podejście do przeszłości przejawia się w dalekim od idealizacji stosunku do konfederacji barskiej57, o czym

53 Por. A.F. Grabski, Pozytywistyczny model historiografii, w: idem, Dzieje historiografii, op. cit., s. 521-557.

54 Georges Cuvier (1769-1832) - francuski biolog, który zajmował się m.in. anatomią porównawczą oraz przyczynił się do powstania współczesnej systematyki zwierząt. Zob. A. Urbanek, Jedno istnieje tylko zwierze.... Myśli przewodnie biologii porównawczej, Warszawa 2007, s. 8-18 i in.

55 Z. Kaczkowski, Od autora, op. cit., s. 40.

56 B. Szleszyński, Przymierzanie kontusza, op. cit., s. 82.

57 Por. „Dążąc do upodobnienia modelu historii do wzoru nauk przyrodniczych i programując jej „podniesienie" do poziomu umiejętności, pozytywistyczna historiografia bardzo często opowiadała się za zasadą sui generis absolutnego (jak gdyby był on w ogóle możliwy) poznawczego o b i e k ty w i z mu w historii oraz jej poznawczej n e u traln ości" (A.F. Grabski, op. cit., s. 553). 
była już mowa. W tekstach nieczujowskich można by wskazać wiele przykładów potwierdzających taką postawę pisarza ${ }^{58}$. Negatywnie na temat konfederacji Kaczkowski wypowiada się również na łamach swojego pamiętnika, podkreśla bowiem finansowe nadużycia ze strony jej uczestników. Opinie pisarza na temat powstań $\mathrm{w}$ podobnym tonie utrzymane są $\mathrm{w}$ tekście zatytułowanym Romantyzm. Ponadto dążenie sanoczanina do obiektywizacji sądów widać choćby w wyraźnym unikaniu przez niego skrajności, co znajduje wyraz w ukazywaniu zarówno negatywnych, jak i pozytywnych aspektów tradycji sarmackiej, a zwłaszcza konfederacji barskiej. Taki sposób opisu przeszłości (dążenie do obiektywizmu poznawczego w historii oraz do poznawczej neutralności) sprawia, że w postawie pisarza można wskazać cechy charakterystyczne dla warszawskiej szkoły historycznej ${ }^{59}$. Poświadczeniem unikania przez Kaczkowskiego stronniczości jest również fakt, że paradoksalnie w jego postawie wobec sarmackiej przeszłości można znaleźć elementy znamienne dla poglądów krakowskiej szkoły historycznej. Najpełniej ujawnia się to w kreacji największego bohatera konfederacji barskiej - Kazimierza Pułaskiego. Pisarz bowiem - choćby w tekście Bitwa pod Widawq - obok jego cech pozytywnych wskazuje również te negatywne (na przykład brak rozwagi i doświadczenia, a także to że, podejmując ważne decyzje, nikogo się nie radzi1). Niechęć Kaczkowskiego do skrajności ujawnia się zatem $\mathrm{z}$ jednej strony $\mathrm{w}$ takim podejściu do historii, które znamienne jest dla naukowego badania przeszłości (o zakrojonych na szeroką skalę i prowadzonych przez kilka lat studiach źródłowych obszernie pisze w tekście wstępnym Od autora), z drugiej natomiast strony - jego pojmowanie historii (rozumianej jako dzieje rodzin, co dokumentuje Mój pamiętnik) nie było w pełni zbieżne z pozytywistycznym programem reformy nauki historycznej, propagowanej choćby przez Henry'ego Thomasa Buckle'a, polegającej na próbie zastosowania filozofii pozytywistycznej do badań historycznych. W ujęciu Kaczkowskiego nie znajduje bowiem zastosowania deterministyczny model historii - w cyklu nieczujowskim jego miejsce zajmuje prowidencjalistyczna teoria dziejów - bardzo mocno akcentowana przez odwołania do filozofii stoickiej, propagowanej na gruncie literatury polskiej przez Jana Kochanowskiego. Należy przy tym mocno podkreślić, że autor

58 Niepochlebne obrazy zachowań i motywów konfederatów zawierają takie teksty, jak na przykład Pan Bal (krytyka skłonności konfederatów do kłótni), Edmund Chojnacki (udział w konfederacji barskiej i wielkie w nią zaangażowanie doprowadziło tytułowego bohatera do tragedii życiowej) czy powieść Mąż szalony (zupełnie przypadkowe przystąpienie szlachty sanockiej do konfederacji barskiej - był to jedynie fortel użyty przez rozsądnych Sanoczan, który pozwolił zakończyć awanturę, jaka wywiązała się pod kościołem).

59 Por. stwierdzenie: „w polskiej nauce historycznej, gdzie również historiografia uprawiana według pozytywistycznego wzorca historii jako nauki stała się jednym ze standardowych modeli uprawiania dziejopisarstwa. Stało się to głównie za sprawą tzw. warszawskiej szkoły historycznej, która jako kierunek historiograficzny wystąpiła na przełomie lat siedemdziesiątych i osiemdziesiątych XIX wieku". (A.F. Grabski, op. cit., s. 551). 
Męża szalonego wykorzystuje w swoich utworach nawet fragmenty pieśni autora Odprawy postów greckich jako motta ${ }^{60}$. Postawę historyka-badacza, którą Kaczkowski przyjął w tekście Od autora poprzedzającym zbiorowe wydanie jego dzieł, można łączyć z podkreślaną przez Feliksa Grabskiego, a datowaną na drugą połowę XIX wieku profesjonalizacją nauki historycznej.

Współcześnie - wbrew pozorom - niejednoznaczna postawa Kaczkowskiego wobec tradycji sarmackiej, a tym samym „utrata” mitycznych wyobrażeń o szlacheckiej przeszłości jest nadal aktualnym problemem. Najlepszym tego świadectwem jest choćby poświęcenie całego numeru „Tekstów Drugich”(I/2015) zagadnieniu zwrotu sarmackiego ${ }^{6 \mathrm{r}}$. Jego lektura uświadamia, że ten obszar badawczy niezmiennie wzbudza różnorodne emocje, podobnie jak „bard” Kaczkowski, prezentujący, jak się okazuje, postawę dążącą do racjonalizmu i obiektywnego opisu.

\section{Bibliografia:}

Barycz H., Rzeszowianin Szczesny Morawski 15 V1818-10 IV 1898, w: Sz. Morawski, Pobitna pod Rzeszowem. Powieść prawdziwa z czasów konfederacji barskiej z roku 1769, wyd. 3, Rzeszów 2004;

Barwiński E., Zygmunt Kaczkowski w świetle prawdy (1863-1871). Z tajnych aktów b. austriackiego ministerstwa policji, Lwów 1920;

Bednarczyk-Sołtys W., Zygmunt Kaczkowski - „Olbrachtowi rycerze”, w: Powieś polska XIX wieku. Interpretacje $i$ analizy, pod red. L. Ludorowskiego, Lublin 1992;

Bibliografia literatury polskiej „Nowy Korbut”, oprac. zespół pod kier. I. Śliwińskiej i S. Stupkiewicza, t. 8. Romantyzm: hasta osobowe K-O, Warszawa 1969, s. 11-15 (hasło: Kaczkowski Zygmunt);

Bujnicki T., „Trylogia” w kontekście dziewiętnastowiecznej porwieści historycznej, „Przegląd Humanistyczny” 1992, nr 6;

Burkot S., Uwiktani w historię. Szkice o literaturze, autorach i utworach XIX i XX wieku, Kraków 2008;

Bystrzyca A., Życie jak powieśc. W stulecie śmierci Zygmunta Kaczkowskiego, „Forum Polonijne” 1996, nr 3(9);

Chmielowski P., Zygmunt Kaczkowski. Jego życie i dziatalność literacka. Zarys biograficzny, Petersburg 1898;

Cenckiewicz S., Agent Heubauer, „Wprost” 2008, nr 9;

Chrzanowski I., Zygmunt Kaczkowski. (Zarys życia i dziatalności) w: Z. Kaczkowski, Wybór pism, t. 1, 1900;

Czachowski K., Między romantyzmem a realizmem, oprac. A. Czachowski, wstępem poprzedził J. Maciejewski, Warszawa 1969;

60 Na przykład fragment Pieśni LX Kochanowskiego („Kto tak mądry, że zgadnie / Co nań jutro przypadnie? / Sam Bóg wie przyszłe rzeczy, a śmieje się z nieba, / Kiedy się człowiek troszczę więcej niźli trzeba.") został przywołany jako motto do powieści Murdelio, w której bohater cyklu - Marcin Nieczuja - doświadcza życiowej tragedii (śmierć ukochanej żony i nowonarodzonych bliźniaków). W tym kontekście przytoczone motto w sposób wymowny nawiązuje do umiarkowanych poglądów pisarza.

Kaczkowski mottem zaczerpniętym z twórczości Kochanowskiego opatrzył także Grób Nieczui oraz Kasztelaniców lubaczewskich.

61 Por. także: P. Czapliński, Resztki nowoczesności. Dwa studia o literaturze i życiu, Kraków 2011. 
Czapliński P., Resztki nowoczesności. Dwa studia o literaturze i życiu, Kraków 2011;

Duda S., Wiedeńska wtyczka. Historia galicyjska, „Gazeta Wyborcza” 2014, nr 138, dodatek „Ale Historia” nr 24;

Eco U., Pomiędzy autorem i tekstem, w: idem, Interpretacja i nadinterpretacja, tłum. T. Bieron, Kraków 2008;

Fras Z., Suleja W., Poczet agentów polskich, Wrocław 1995;

Grabski A. F., Dzieje historiografii, wprowadzenie R. Stobiecki, Poznań 2003;

Hegel G.W.F., Fenomenologia ducha, tłum. Ś.F. Nowicki, Warszawa 2010;

Humeniuk A., Portret Karola Radziwitta „Panie Kochanku” w cyklu radziwittowskim J.I. Kraszewskiego, w: Kraszerwski i nowożytność. Studia, idea i układ tomu J. Eawski; red. nauk. A. Janicka, K. Czajkowski, Ł. Zabielski, Białystok 2015;

Inglot M., Poglady literackie koterii petersburskiej w latach 1841-1843, Wrocław 1961;

Jeske-Choiński T., Historyczna powieść polska. Studium krytyczno-literackie (od Niemcewicza do Kaczkowskiego), Warszawa 1899;

J.I. Kraszewski, oprac. W. Danek, Warszawa 1965;

Jopek A., Bard szlachty sanockiej. Opowiadania i powieści historyczne Zygmunta Kaczkowskiego, Kraków 1974 ;

Jopek A., Dwie powieści Zygmunta Kaczkowskiego o dwóch konfederacjach. („Sodalis Marianus” i „Anuncjata”), Rzeszów 1965;

Jopek A., Ziemia krośnienska w twórczości Zygmunta Kaczkowskiego, Rzeszów 1966;

Kaczkowski Z., Bitwa pod Widawq. Rapsod wojenny, „Dziennik Literacki” 1852, nr 20-22;

Dziedzic Strwiążyka. Powieść z czasów rozbioru, Pamiętnik Literacki. Pismo Tygodniowe” R. I, 1850, nr 28-29;

Dzieta, t. 1-3, Warszawa 1874;

Murdelio, Kraków 1974, Rzeszów 1989, Kraków 2003;

Olbrachtowi rycerze, Warszawa 2012;

Opowiadania Nieczui, Kraków 1962;

Pan Bal, „Gazeta Lwowska” 1852, nr 18-19, 21-22, 24;

Rewolucyjne sądy i wyroki. Rzecz osobista, Paryż i Wiedeń 1866;

Kijas J., Kaczkowski jako wspótzawodnik Sienkiewicza, Kraków 1926;

„Koń ma duszę w sobie”, wybór Ł. Ginkowa, Kraków 1988;

Kowalik A., Zygmunt Kaczkowski, cztowiek i pisarz, czyli twórczośc w smudze cienia, w: Ziemia krośnieńska w kulturze polskiej, pod red. H. Kurek, F. Tereszkiewicza, Kraków 1996;

Koźmiński M., A. Sieroszewski A., O stereotypie Polaka i Wegra w XIX i XX w., Warszawa 1980;

Kraszewski J.I., Obrazy przesztości, w: Kraszewski o powieściopisarzach i powieści. Zbiór wypowiedzi teoretycznych i krytycznych, oprac. S. Burkot, Warszawa 1962;

Krechowiecki A., Zygmunt Kaczkowski i jego czasy. Na podstawie źródet $i$ materiatów rękopiśmiennych, Lwów 1918;

Micińska M., Zdrada - córka nocy. Pojęcie zdrady narodowej w świadomości Polaków w latach 1861-1914, Warszawa 1998;

Motywy modlitewne w prozie polskiej XIX i XX wieku, wybór i oprac. A. Bednarek, Niepokalanów 1988;

Nawarecki A., hasło: Sarmatyzm, w: Stownik sarmatyzmu, Kraków 2002; 
Olszewska M.J., Opowieśc o Bogu karzacym (Zygmunt Kaczkowski, Olbrachtowi rycerze), w: eadem, Drogi nadziei. Polska proza historyczna z lat 1876-1939 wobec kryzysu kultury. Wybór, Warszawa 2009;

Pol W., Pamiętnik Wincentego Pola do literatury polskiej XIX wieku, w dwudziestu prelekcjach mianych w radnej sali miasta Lwowa, stenografowanych pod dyrekcja L. Olewińskiego, profesora stenografi w Uniwersytecie Lwowskim, Lwów 1866;

Sieroszewski A., Pierwsze powieści historyczne Mora Jokaiego i Zygmunta Kaczkowskiego, w: Z dziejów polsko-węgierskich stosunków historycznych i literackich, pod red. I. Csaplárosa i A. Sieroszewskiego, Warszawa 1979;

Sieroszewski A., Wegierska i polska powieść historyczna w dobie romantyzmu, Warszawa 1977;

Słoka E., Roślinność romantycznego cmentarza, w: Literacka symbolika roślin, pod red. A. Martuszewskiej, Gdańsk 1997;

Szleszyński B.: Zygmunt Kaczkowski - między Pamiątkami Soplicy i Trylogia, w: idem, Przymierzanie kontusza. Henryk Rzewuski i Henryk Sienkiewicz - najwybitniejsi twórcy XIX-wiecznego nurtu sarmackiego, Warszawa 2007;

Sarmacka codziennośc w powieściach Henryka Rzewuskiego, Zygmunta Kaczkowskiego i Henryka Sienkiewicza, w: Codziennośc w literaturze XIX (i XX) wieku. Od Adalberta Stiftera do wspótczesności, pod red. G. Borkowskiej i A. Mazur, Opole 2007;

Twórczośi Zygmunta Kaczkowskiegowoczachkrytyki(1851-1863),w:Dyskursy krytycznoliterackie 1764-1918. Wokót Stownika polskiejkrytyki literackiej,t.2, pod red.M. Strzyżewskiego, Toruń 2012;

Szweykowski Z.: „Murdelio” Zygmunta Kaczkowskiego, w: idem, Nie tylko o Prusie. Szkice, Poznań 1967;

Powieści historyczne Henryka Rzewuskiego, Warszawa 1922;

Wstęp do: Z. Kaczkowski, Murdelio. Powiesé, Kraków 1925;

Ślisz A., Henryk Rzewuski. Życie i poglądy, Warszawa 1986;

Urbanek A., Jedno istnieje tylko zwierzę... Myśli przewodnie biologii porównawczej, Warszawa 2007;

Waśko A., Romantyczny sarmatyzm. Tradycja szlachecka w literaturze polskiej lat 1831-1863, Kraków 1995;

Węgrzyn I., W świecie powieści Henryka Rzewuskiego, Kraków 2012.

SŁowA KLucze: Zygmunt Kaczkowski, nurt sarmacki w literaturze polskiej XIX wieku 


\section{Agnieszka Szczechura (Humeniuk) \\ Zygmunt Kaczkowski and the Sarmatian tradition in the Nieczuja CYCLE}

The aim of the article is to describe the attitudes of Zygmunt Kaczkowski in the context of the Sarmatian tradition. When analysing the writer's attitude to Sarmatism on the basis of the texts which belong to the Nieczuja cycle, it has been noticed that the writer "lost" the mythical imagination about the past for the sake of the objective description.

Key words: Zygmunt Kaczkowski, the Sarmatian tradition in Polish literature of the $19^{\text {th }}$ century 